\title{
ENTRE A SEDUÇÃO E O SONHO: \\ UMA LEITURA DE “O HOMEM DOS SONHOS”, DE MÁRIO DE SÁ-CARNEIRO, À LUZ DA FILOSOFIA DE SÖREN KIERKEGAARD
}

\section{BETWEEN SEDUCTION AND DREAM: A READING OF “O HOMEM DOS SONHOS”, BY MÁRIO DE SÁ-CARNEIRO, UNDER THE LIGHT OF SOREN KIERKEGAARD'S PHILOSOPHY}

\author{
Márcia Manir Miguel Feitosa \\ Universidade Federal do Maranhão, São Luís, MA, Brasil \\ Leonardo Silva Sousa \\ Universidade Federal do Maranhão, São Luís, MA, Brasil
}

Resumo: O objetivo deste trabalho consiste em aproximar a Filosofia de Sören Kierkegaard (1813-1855) da Literatura de Mário de Sá-Carneiro (1890-1916), por meio da análise da personagem "O russo", do conto O homem dos sonhos. À luz da estadia estética em Kierkegaard, inspirada na obra Diário de um sedutor, será possível identificar aproximaçóes e afinidades entre as personagens e como se desenvolve esse estádio existencial no pensamento do filósofo dinamarquês.

Palavras-chave: Filosofia; Literatura; existência.

Abstract: This article's goal is to approximate Soren Kierkegaard's Philosophy (1813-1815) of Mário de Sá-Carneiro's Literature (1890-1916), by means of the analysis of the character known as "Russian" from the short-story $O$ homem dos sonhos. Under the light of Kierkegaard's aesthetic stay, inspired on his book Diary of a seducer, it will be possible to identify approximations and affinities between the characters and how this existential phase develops in the Danish philosopher's thinking.

Keywords: Philosophy; Literature; existence.

\section{Introduçáo}

Devemos considerar Sören Kierkegaard (1813-1855) como um pensador que buscou atingir o íntimo de seus contemporâneos e demais leitores de sua vasta produção filosófica. O "irônico de Copenhague", se assim quisermos chamá-lo, desenvolveu uma filosofia dirigida para a abordagem psicológica do ser humano, pautada na possibilidade de o indivíduo nutrir 
uma relação responsável com a existência, reconhecendo-se enquanto um ente mediado por possibilidades que poderáo ser decisivas no decorrer de sua jornada existencial.

Para esmiuçar questôes envolvendo os dilemas e os dramas enfrentados pelos indivíduos em suas estadas existenciais, Kierkegaard construiu uma obra dividida em escritos estéticos e religiosos ${ }^{1}$; obras que se iniciam desde a juventude, quando defendeu, em 1841, a dissertação Sobre o conceito de ironia constantemente referido a Sócrates. A partir daí, Kierkegaard não iria parar e, embora venha a falecer no ano de 1855, nos legou uma vasta obra que direciona aqueles que se interessam por suas ideias a náo somente pensarem a existência e como ela se desdobra a partir de seu texto filosófico, mas a repensarem as próprias vidas pelo jogo dialético marcado pela ironia filosófica e sua maiêutica, ambas herdadas de Sócrates, seu mestre da antiguidade.

E quanto a Mário de Sá-Carneiro (1890-1916)? Um dos poetas da Geraçáo de Orpheu, figura ímpar da Literatura Portuguesa do início do séc. XX e herdeiro do decadentismo francês de Baudelaire, assim como Kierkegaard, se não produziu uma obra tão vasta quanto a do filósofo dinamarquês, náo se eximiu de abordar temáticas surreais sobre a existência humana. Sá-Carneiro não era filósofo, mas poeta que soube tratar da fragilidade da vida humana com extrema sensibilidade e inteligência.

A proposta deste artigo é aproximar a Literatura da Filosofia. Analisaremos, portanto, o conto $O$ homem dos sonhos, do livro Céu em fogo, de Sá-Carneiro (1915), pela perspectiva do estádio estético, tendo como referência a obra Diário de um sedutor (1843), do filósofo dinamarquês. Serão apresentados, inicialmente, alguns aspectos da filosofia existencial de Kierkegaard, em especial a sua comunicação indireta e a afinidade desse método com as estadias existenciais. Posteriormente, a reflexão incidirá sobre a estadia estética preconizada pelo pseudônimo Johannes para, finalmente, dialogar com o conto de Sá-Carneiro.

\footnotetext{
${ }^{1}$ Há, na obra filosófica de Kierkegaard, um duplo caráter: “[...] esta duplicidade é consciente, o autor está dela melhor informado do que ninguém, ela é condição dialética fundamental de toda obra e tem como consequência uma razão profunda" (KIERKEGAARD, 1989, p. 29). Desde a juventude, Kierkegaard intercambia sua produção filosófica entre escritos estéticos e religiosos. A produção estética corresponde a uma escrita sofisticada e com contornos poéticos, valendo-se de pseudônimos que expốem temáticas subjacentes à existência. Já os escritos religiosos não levam a assinatura de pseudônimos. São obras com comunicação direta e provocativa com o leitor. A meta dos escritos estéticos, em especial, tencionar a reflexão sobre o problema desenvolvido pelo pseudônimo, o que demonstra a natureza edificante de sua filosofia.
} 


\section{Kierkegaard e a comunicaçáo existencial: sobre os pseudônimos e as possibilidades de existência}

Kierkegaard desenvolve sua filosofia a partir de estados psicológicos que cingem o homem, como o desespero, a angústia, a repetição ou o instante. Ele parte da existência e não de uma ideia ou conceito sobre ela, contrapondo-se ao idealismo alemão, famoso movimento filosófico que tinha como principal meta a explicação racional da realidade e dos acontecimentos históricos dentro de um sistema filosófico, já que, na ideia de sistema, tudo que existe no mundo sensível seria senáo movimento do absoluto, uma potência somente intuída pelo ser humano. Os sistemas filosóficos dos idealistas alemães, em especial o de G. W. F. Hegel (17701831), tentariam, inclusive, argumentar a respeito da existência individual do ser humano, explicando racional e teoricamente as experiências do homem. Mas, afirma Kierkegaard ([1844] 2011, p. 60) em suas Migalhas filosóficas, "o maior paradoxo do pensamento é querer descobrir algo que ele próprio não possa pensar”. Para Kierkegaard, o indivíduo pode ser tomado por fenômenos intraduzíveis pela razão, como a experiência da fé, considerada um verdadeiro paradoxo, pois, pela fé, tomamos consciência de que "o interior é superior ao exterior, ou, para retomar uma fórmula precedente, o número ímpar é superior ao número par" (KIERKEGAARD, 1979, p. 150). Nesse ponto, a Filosofia de sua época é incapaz de explicar este fenômeno objetivamente, sendo ela uma ação subjetiva mediada pelo indivíduo em contato com Deus. $\mathrm{O}$ autor dinamarquês oferece uma filosofia "centrada nos dramas e contradiçôes que percorrem, no interior da existência, o ato de existir do próprio existente" (ALMEIDA; VALLS, 2007, p. 33).

Se a preocupação de Kierkegaard é com o existir e a capacidade de o indivíduo atingir as respostas para seus questionamentos no interior da existência, devemos atentar para a relevância de sua comunicação indireta ${ }^{2}$,

\footnotetext{
2 "Que é necessário para levar alguém, com um verdadeiro sucesso, a um ponto preciso? Ter antes de mais nada o cuidado de o cativar e começar onde ele se encontra" (KIERKEGAARD, 1986, p. 45). A comunicação indireta trata de partir da situaçấo em que o leitor se encontra, situação de sujeito existente que necessita desenvolver uma reflexão desdobrada sobre sua condição existencial. Por isso, Kierkegaard trabalha com uma infinidade de pseudônimos que possui singularidade e que assina seus textos; cada um divergindo-se uns dos outros, como Johannes Climacus (1843), o autor cético de Migalhas filósoficas, e Anti-Climacus (1848), o autor religioso de $\mathbf{O}$ desespero humano. Nas palavras de Almeida e Valls, Kierkegaard quer que sua obra se configure como um espelho, ou seja, "o objetivo não é ver o espelho, mas enxergarse nele, transferindo ao leitor a tarefa de aprofundar-se e tomar as decisóes fundamentais que a existência requer" (ALMEIDA; VALLS, 2007, p. 13).
} 
método literário utilizado pelo autor e capaz de gerar uma "descarga" de tensão e reflexão sobre o leitor, inserindo-o em seu jogo irônico e maiêutico. Valendo-se desse artifício, o pseudônimo obriga o leitor a refletir sobre o problema, intimando-o a buscar, quando possível, um instante de afastamento e resignação para pensar sobre sua existência e os graus de precariedade em que ela se encontra.

Kierkegaard é notavelmente reconhecido pela criação de pseudônimos que assinalam suas obras. Através desses "eus-autorais", o autor apresenta as possibilidades de existência, o que nos leva às estadias existenciais que se desdobram em suas obras. Kierkegaard trabalha sob o modelo de três possibilidades: a estética, a ética e a religiosa. A estadia estética corresponde àqueles seres mergulhados na temporalidade, experimentando-a com intensidade. $\mathrm{O}$ esteta movimenta-se no instante, preso no tempo-presente, intensificando suas açôes. Segundo Grammont (2003, p. 111):

As personagens que se colocam no estádio estético derramam-se aos nossos olhos com a turbulência de um rio que corre sem cessar. Vivem no instante, na busca desenfreada de um gozo sem passado e sem futuro. Mesmo quando se aproximam da dor, surgem dionisíacas, ou semi-ocultas por uma atmosfera lunar.

Kierkegaard busca refletir a existência estética por meio de três figuras míticas: Don Juan, que representa o movimento da sensualidade, Fausto, que representa a dúvida, e Judeu Errante, que representa a categoria do desespero. Pelas influências dessas personagens, em especial Don Juan, forja o pseudônimo Johannes - $\mathrm{O}$ sedutor, que, semelhante ao famoso personagem da obra de Móliere e da ópera de Mozart, movimenta-se para a sensualidade, mas de maneira reflexiva: "se mostra como sendo a linguagem e a reflexão, por meio das quais vão se concretizando as determinaçóes do sensível por ele protagonizadas" (PROTÁSIO, 2014, p. 91). No estético, o sujeito se delicia com suas experiências no fluxo do presente, pois nem o futuro e nem o passado lhe pertencem, a não ser que possam oferecer oportunidades para que um gozo venha a ser alcançado.

$\mathrm{O}$ esteta não possui responsabilidade com a existência e o desejo em comprometer-se com os outros. Contrapóe-se a estadia ética em Kierkegaard, cujas qualidades se apresentam com veemência. Gilles (1975, p. 20) nos indica que:

No estádio ético, o Indivíduo torna-se consciente de ser responsável, mas, por outro lado, torna-se consciente do peso do universal, isto é, da 
necessidade de assumir a forma de existência que a coletividade lhe impóe, pois ele é submisso à lei em toda sua generalidade [...] Nesse estádio o Indivíduo se renova constantemente, pois o passado se torna presente e o presente se torna perpetuamente renovável no futuro. O futuro é garantido pela própria reafirmação ética, dando estabilidade ao presente. No estádio ético a existência se renova na permanência.

O cuidado com a própria existência é estendido aos outros em suas decisóes, não visando apenas a uma satisfação pessoal, mas também coletiva. Para Farago (2006), o homem ético aproxima-se da ética racional do iluminista Immanuel Kant (1724-1804) quando apresentada em sua segunda crítica. Agindo racionalmente e de maneira objetiva, o homem ético almeja que sua ação atinja um grau universal. Ele não teme pela continuidade de suas açôes, visto que elas serão capazes de reafirmar o quanto foram conscientes e necessárias. O tempo-presente se apresenta como o movimento da decisão ${ }^{3}$ e o futuro como reafirmação de uma decisão que, numa ocasião anterior, alcançou sua finalidade. Daí o homem ético não temer a continuidade ou a possibilidade de rotina, dado que seus hábitos e escolhas poderão ser renovados. Síntese entre um passado que se torna presente e um presente perpetuamente renovável, como pontua Gilles (1975).

O estádio religioso é a terceira possibilidade de existência considerada por Kierkegaard. É nesta estadia que o indivíduo percebe Deus, desenvolvendo uma relação com aquilo que o pôs no mundo. $\mathrm{O}$ alcance da eternidade é possível por meio de uma síntese entre temporalidade e eternidade, quando o homem pode atingir o esclarecimento de sua existência pela fé, conservando a experiência do infinito após a efetuação do salto para a fé. Kierkegaard nos revela essa experiência intraduzível pelo poeta Johannes de Silentio (1843), pseudônimo de Temor e tremor, que analisa a interessante história de Abraão, batizado pelo pseudônimo de "o cavaleiro da fé".

No estádio religioso, o indivíduo se propóe a desenvolver um movimento de reconciliaçáo com Deus, sua fonte original. Para o filósofo moderno, o homem do estádio religioso realiza um movimento dialético, visto consistir "[n] uma síntese de infinito e finito, de temporal e de eterno, de liberdade e necessidade [...]" (KIERKEGAARD, 1979, p. 195). Tais elementos se encontram em relação desarmônica. $\mathrm{Na}$ obra $\mathbf{O}$ desespero humano, Kierkegaard ([1849] 1979) afirma que:

\footnotetext{
${ }^{3}$ Nas reflexôes de Protásio (2014), é a decisão que caracteriza a estadia ética em Kierkegaard (1843), que vem à tona com o Wilhelm, o Juiz, pseudônimo que aparece em "O equilíbrio entre o estético e o ético na formação da personalidade", um dos textos que compôem a coletânea A alternativa. Diferente do esteta, o homem ético decide pela sua existência, vivendo em mediania e equilíbrio com suas escolhas.
} 
O homem é espírito. Mas o que é o espírito? É o eu. Mas, nesse caso, o eu? $\mathrm{O}$ eu é uma relação que nấo se estabelece com qualquer coisa de alheio a si, mas consigo própria. Mais e melhor do que na relação propriamente dita, ele consiste no orientar-se dessa relação para a própria interioridade. $\mathrm{O}$ eu não é relação em si, mas o seu voltar-se sobre si própria, o conhecimento que ela tem de si própria depois de estabelecida (KIERKEGAARD, [1849] 1979, p. 195).

O homem é espírito, nas palavras de Kierkegaard. Um espírito que se coloca em movimento a partir da relação dialética da síntese que o constitui, sendo o Eu a qualidade eterna e aquilo que nos aproxima da força que nos criou. Abraáo, considerado o cavaleiro da fé pelo pseudônimo Johannes de Silentio, apresenta-se como o exemplo de homem que, ao tentar sacrificar o filho Isaac para cumprir a obediência do dever divino, adquire um "segundo nascimento", alcançando, assim, a eternidade. Ao se esforçar para conservar esta experiência, sintetiza infinito e finito, liberdade e necessidade.

Pelas estadias estética, ética e religiosa, Kierkegaard desvela o quanto o indivíduo está lançado em um grande terreno de possibilidades, sendo a existência em si caracterizada pelo seu processo de movimento, de modo que o indivíduo pode saltar para uma estadia ou regressar para a situação em que se encontrava. Para Almeida e Valls (2007), há em Kierkegaard a tentativa de desenvolver uma fenomenologia e uma dialética da liberdade, a partir dos estádios, não como etapas sucessivas, mas especialmente descritas como possibilidades de existência marcadas pela "tensão que caracteriza as possibilidades de concretizar a aventura do deixar de ser para tornar-se homem, como evocou Píndaro: 'Vem a ser, na própria experiência, aquele que és" (ALMEIDA; VALLS, 2007, p. 34).Vejamos, pois, quem é Johannes, pseudônimo da novela filosófica Diário de um sedutor.

\section{Johannes de Diário de um sedutor}

Quem é Johannes? Valls (1988, p. 125) o define como "um motor imóvel, que ocasiona o movimento, as vibraçóes afinadas na pessoa amada, ou para ser mais exato, na jovem que é objeto das atençôes”. Esse personagem é um sedutor, mas, acima tudo, um artista que se empenha em trabalhar uma arte, a sedução, que não consiste simplesmente em um ato de conquista, mas aquilo que compóe um método produzido pelo seu esforço intelectual e poético.

O sedutor possui uma relação de necessidade com a sedução, pois parece não ser capaz de efetuar suas possibilidades fora de seu método. 
Assim, Johannes tenta se conservar ao máximo no ambiente de experiências de sedução, mesmo que não esteja atuando no instante de sua prática. Para isso, utiliza a chamada reflexão poética. De acordo com Grammont (2003, p. 23), "a ideia de reflexão poética está associada ao prazer e à vida como possibilidade, característica do estádio estético, e, sobretudo, de um esteta”. Por meio dessa estratégia, o esteta retoma as experiências prazerosas que obteve e, sob o exercício intelectual, intensifica o instante de prazer, proporcionando intensidade e movimento à seduçáo. Para tanto, vale-se de cartas endereçadas a uma moça chamada Cordélia Wahl, seu alvo de ataque. Seja uma dessas missivas:

\begin{abstract}
Minha Cordélia!
$\mathrm{O}$ que é o desejo? A língua e os poetas fazem rimar desejo e prisão. Que absurdo! Como se aquele que está na prisão pudesse arder em desejo! Se eu fosse livre, como arderia! E, por outro lado, sou livre como um pássaro e, acredita-me, ardo em desejo - sinto-o ao ir para tua casa e quando te deixo, e, ainda quando estou sentado a teu lado, ardo em desejo por ti. Mas poder-se-á então desejar aquilo que se possui? Sim, quando pensamos que, no instante seguinte, o não possuímos já. $\mathrm{O}$ meu desejo é uma impaciência eterna. Se eu tivesse vivido todas as eternidades e ganho a certeza de que me pertences em todos os seus instantes, só entáo estaria junto de ti e viveria contigo todas as eternidades - certamente não teria paciência bastante para estar um só momento separado de ti sem arder em desejo, mas possuiria a confiança suficiente para me manter calmo a teu lado. Teu Johannes (KIERKEGAARD, 1979, p. 70).
\end{abstract}

$\mathrm{Na}$ carta, o esteta se declara livre como um pássaro, e, mesmo ao ir embora da casa da jovem moça, conserva a sua presença ao arder em desejo. Seria essa uma forma de exercitar sua reflexão poética, usufruindo do instante agradável por meio de seu gênio. Nesse ponto, "o esteta não vive, ele pensa, assiste a si próprio e a seus atos e essa reflexão constitui o gozo que vivencia" (GRAMMONT, 2003, p. 23).

"Pessoalmente não procuro histórias - verdade se diga, não encontrei poucas -, procuro o imediato" (KIERKEGAARD, 1979, p. 61). Ao proferir essas palavras, Johannes demonstra os passos de sua existência fundada em viver no imediato. Conservando-se na imediatez, "o sedutor vive o instante com toda intensidade possível. Consome-se na tarefa de fazer-se amar para abandonar em seguida" (GRAMMONT, 2003, p. 26). Não prima pelo compromisso, o que busca é um prazer inebriante, no instante ${ }^{4}$ em que se

\footnotetext{
${ }^{4}$ Nas consideraçóes de Protásio (2014), o instante diverge daquele trabalhado por Kierkegaard em Migalhas filosóficas. Caracteriza-se como uma oportunidade que se apresenta para o esteta e a qual ele deve se agarrar para realizar o movimento da sedução. Segundo a autora, "Johannes pensa a oportunidade como determinante da vida, e por isso náo pode perdê-la, uma vez que
} 
oferece uma oportunidade a ser fisgada.

Diário de um sedutor é repleto de cartas direcionadas à Cordélia, as quais detêm um objetivo central no desenrolar da trama. É pelas cartas que a moça encanta-se com a genialidade do esteta e é por elas que Johannes pode possuí-la espiritualmente, obtendo seu controle: "as cartas, afinal, são e serão sempre um meio inapreciável para causar determinada impressão numa jovem; as palavras escritas têm, bastas vezes, uma influência muito maior que a palavra viva" (KIERKEGAARD, 1979, p. 85). Para o sedutor, a linguagem escrita legitima a capacidade de atingir com maior intensidade a alma de Cordélia. Pelas cartas, Cordélia se inflama, despertando sua natureza erótica, motivo maior da relaçáo do esteta com a jovem. Logo, as cartas possuem uma finalidade para a concretização de seu objetivo: "as cartas acertam no alvo. Desenvolvem a sua alma, o seu erotismo" (KIERKEGAARD, 1979, p. 71).

Segundo Valls (1988, p. 125), “o poeta romântico não escreve apenas poemas, mas quer viver o que escreve, ou poetizar sua existência”. Johannes é um típico esteta romântico e o que pretende com as cartas é viver poeticamente. Ignora, além disso, qualquer compromisso ético por dificultar sua atuaçáo artística, enjaulando-o na gaiola das convençóes sociais. Johannes é, por assim dizer, o "náo social", o que lhe garante motivo de orgulho, visto considerar-se uma criatura erótica. Desdenha e ironiza aqueles que se ocupam em estabelecer vínculos éticos, mas, curiosamente, firma um noivado com a jovem Cordélia, ainda que de fachada:

De entre todas as coisas ridículas, é o noivado que tem o primeiro lugar. $\mathrm{O}$ casamento tem, pelo menos, um sentido, embora seja um sentido pouco cômodo para. $\mathrm{O}$ noivado é uma invençăo puramente humana e não traz honra a quem o inventou. Náo é nem carne nem peixe, e assemelha-se tâo pouco ao amor como a faixa nas costas do bedel à toga de um professor (KIERKEGAARD, 1979, p. 57).

Uma realidade poética só é possível para aqueles que se afastam da realidade física e buscam, pelo esforço do intelecto, desenvolver um habitat para que seus sonhos e possibilidades sejam concretizados. É pela sedução que Johannes cria seu próprio ambiente, lançando mão de Cordélia para o

liga o sentido da vida às oportunidades que a vida traz" (PROTÁSIO, 2014, p. 93). Daí, a importância do "instante estético", oferecendo sentido e significado para a vida de Johannes. Os instantes oportunos são analisados pelo esteta com enorme precisão, pois "a oportunidade é sempre única, o que significa dizer que, se ele a oportunidade deixa passar, ela não retorna" (PROTÁSIO, 2014, p. 93). 
desenvolvimento do seu método artístico. De posse desses apontamentos, direcionemos nosso olhar para o conto de Mário de Sá-Carneiro.

\title{
3. "Sonhar a vida, viver o sonho" - Sá-Carneiro à luz de Kierkegaard
}

O modernista português presenteia os amantes de sua escrita em prosa poética com esta curiosa narrativa da coletânea Céu em Fogo (1915), série de oito contos fascinantes em que o mistério e o fascínio pela arte caracterizam a maioria dos personagens, considerados "artistas plenamente realizados, social e esteticamente, bafejados pela glória, pelo dinheiro e pelo gênio" (BUENO, 1995, p. 22). Os personagens sá-carneirianos desfrutam de um ócio criativo a fim de vivenciar experiências que ultrapassem o cotidiano popular. Pela contemplaçáo artística, a vida de seus personagens ganha um sentido maior, assim como para seu criador. O russo, de $O$ homem dos sonhos, não foge à risca.

A descrição de suas características físicas e de seu semblante confirmam o seu aspecto diferenciado:

\begin{abstract}
Alto, extremamente alto e magro. Grandes cabelos encrespados, dum loiro triste, fugitivo; e os seus olhos fantasticos de azul, com certeza os olhos mais estranhos que me luminaram algum dia. Só os posso evocar nesta incoerência: eram dum brilho fulgurante - mas não brilhavam (SÁ-CARNEIRO, 1995, p. 481, grifos do autor)
\end{abstract}

Semelhante singularidade desperta atenção do narrador-personagem que o conhece em um Chartier de Paris, no período em que era estudante de medicina, sem grandes pretensóes: "era um espírito interessantíssimo; tinha opinióes bizarras, idéias estranhas - como estranhas eram suas palavras, extravagantes os seus gestos. Aquele homem parecia-me um mistério. Náo me enganava, soube-o mais tarde: era um homem feliz" (SÁ-CARNEIRO, 1995, p. 476, grifos do autor). Possui um gênio excêntrico e uma disposição para revelaçóes tidas como anormais para o narrador-personagem:

Tem razão, muita razão! É uma coisa horrível esta vida - tão horrível que se pode tornar bela! Olhe um homem que tenha tudo: saúde, dinheiro, glória e amor. É-lhe impossível desejar mais, porque possui tudo quanto de formoso existe. Atingiu a máxima aventura, e é um desgraçado. Pois há lá desgraça maior que a impossibilidade de desejar!... E creia que náo é preciso muito para chegarmos a tamanha miséria. A vida, no fundo, contém tão poucas coisas, se é tấo pouco variada... Olhe, em todos os campos. [..]) $\mathrm{E}$ 
quanto aos sentimentos? Descubra-me algum que, no fim das contas, se não reduza a qualquer destes dois: amor ou ódio. E as sensaçôes? Duas também: alegria e dor. Decididamente, na vida, anda tudo aos pares, como os sexos. A propósito: conhece alguma coisa mais desoladora do que isto de só haver dois sexos? (SÁ-CARNEIRO, 1995, p. 467, grifos do autor).

A vida era uma experiência horrível, sóbria de descobertas e mistérios, visto estar cerceada pela rotina urbana. Para ele, tudo na vida se reduzia aos pares, inclusive o sexo, o que lhe deixava indignado. A realidade é, para o russo, desprovida de criatividade. Nesse ponto, "o que torna o estádio estético singular é o fato de relacionar a sensação de monotonia em relação à existência com a criação poética. Seria preciso negar a existência presente, cotidiana para torná-la estética” (GRAMMONT, 2003, p. 75). A impossibilidade de satisfação na realidade física é que estimula os estetas a criarem. Assim como Johannes, o russo é um personagem ansioso por suprimir um vazio inesgotável em seu ser. Ambos se afastam da vida burguesa comum para apropriarem-se de "outra vida", lapidada com todo cuidado pela criação artística.

$O$ personagem necessita se movimentar, extirpando qualquer oportunidade para que o tédio bata a sua porta, já que a vida humana, como ele mesmo informa, é pueril e nada acrescenta à existência: "é uma coisa impossível - sem variedade, sem originalidade. Eu comparo-a à lista de um restaurante onde os pratos sejam sempre os mesmos, com o mesmo aspecto, o mesmo sabor" (SÁ-CARNEIRO, 1995, p. 467).

$\mathrm{Na}$ estadia estética, o indivíduo distancia-se daquilo que permanece inalterado. Interessa ao esteta desfrutar a cada noite de uma nova possibilidade de prazer ou de um "novo cardápio", para, assim, saciar sua fome titânica. Nesse estádio, "o Indivíduo procura no mar-sem-fundo dos prazeres, como também nas profundezas do conhecimento, um lugar onde poderá lançar a âncora da existência. [...] Sente que pelo menos idealmente é capaz de tudo, é capaz de infinita subjetividade" (GILLES, 1975, p. 16). Assim como o pseudônimo esteta de Kierkegaard, o personagem de SáCarneiro se apresenta como uma personalidade movida por ideias, imagens e representações que cria, sendo, idealmente, capaz de tudo.

Como Johannes, parece possuir seu próprio método e, através das qualidades enquanto artista, conserva sua existência na realidade que cria. $\mathrm{O}$ russo domina seus sonhos, transcendendo sua realidade, direcionando-se a experiências e paisagens que se afiguram intraduzíveis: 
[...] Porque é sonhando que eu vivo tudo. Compreende? Eu dominei os sonhos. Sonho o que quero. Vivo o que quero. [...] Assim parti para uma terra ignorada, perdida em um mundo extra real, onde as cidades e as florestas existem perpetuamente mergulhadas na mais densa treva... Não há palavras que traduzam a beleza que experimentei nessa regiáo singular. Porque eu via as trevas. A sua inteligência não concebe isso, decerto, nem a de ninguém. [...] No recanto de uma rua perdida encontrei dois amantes a morderemse nas bocas. Ai, como deviam ser grandiosos aqueles beijos profundos na suprema negrura das trevas densíssimas!... Mais longe assisti a uma cena de sangue: cruzavam-se estiletes, havia gritos de dor... Nunca vivi um momento mais temível que esse... E, pelos arrabaldes, os vinhedos carregados de frutos, os trigais maduros, as searas e os pomares que o vento balanceava... toda a vida, em suma, toda a vida, na escuridão impenetrável... Que triunfo! Que triunfo!... (SÁ-CARNEIRO, 1995, p. 478, grifos do autor).

Por meio da narração minuciosa, percebemos que os locais e paisagens que vislumbra se relacionam com a tentativa de extrapolar a realidade. Em seu universo onírico, o russo se apraz com o ardente beijo dos amantes, seguido de uma cena de sangue cercada de grito e horror. Tudo isso lhe serve de contemplação artística, e o sonho é a obra que cria na ocasiáo pela qual se deixa interessar.

Graças ao sonho se reconhece como invencível, criando e desfrutando de sua arte. Através dele, o russo aproxima-se de Johannes, que busca ancorar-se na sedução, concedendo-lhe movimento e conteúdo, seja com as cartas para Cordélia, seja com sua imagem idealizada. Johannes e o russo não se arrojam na existência sem a seduçáo e o sonho. De posse de ambos, buscam experimentar o movimento do ilimitado, fugindo do tédio e do cotidiano popular, através das cartas para Cordélia ou da sua imagem idealizada.

Tania Sturzbecher de Barros, na sua dissertação $O$ duplo em Céu e fogo de Mário de Sá-Carneiro, pontua que, em O homem dos sonhos, o sonho aparece como forma de concretizaçáo do real no mundo ideal, desejado pelo protagonista: "[...] Pelo discurso do homem dos sonhos, o sonho constrói novas realidades, superiores à realidade cotidiana e banal que nos circunda" (BARROS, 2003, p. 65-66). Com essa passagem, Barros reforça uma característica vigorante da existência estética: o desapego da realidade da vida comum. Se possível, o esteta torna-se capaz de envolver-se em um isolamento voluntário para criar uma realidade que se configura como fuga do mundo real. Daí essa existência se caracteriza pela tensão entre realidade idealizada x realidade temporal, vontade pessoal x contingência. Almeida e Valls (2007, p. 39) argumentam que "ele sente que tem algo, uma potência em si que quer ser realizada, porém náo se reconhece como um eu que deve deixar de ser imediato como os animais para tornar-se um si mesmo". 
O desfecho do conto descortina um desaparecimento misterioso do russo, com o narrador-personagem refletindo sobre sua personalidade:

\begin{abstract}
Se o homem dos sonhos era uma figura de sonho, mas ao mesmo tempo, uma criatura real - havia de viver uma vida real. A nossa vida, a minha vida, a vida de todos nós? Impossível. A essa existência odiosa ele confessara-me não poder resistir. Demais, nessa existência, - a sua atitude era duma figura de sonho. Sim, duma figura irreal, indecisa, de feiçôes irreais e indecisas. Logo, o desconhecido maravilhoso não vivia a nossa vida. Mas se não a vivia e entretanto surgia vagamente nela, é porque a sonhava (SÁ-CARNEIRO, 2007, p. 482, grifos do autor).
\end{abstract}

O russo é um personagem inadmissível para esse mundo, um ser irrealizável, que procura a conservação de um instante que logo se esvai quando da criação e contemplação. Logo, "o esteta é uma espécie de paradigma dessa concepção 'artística' de mundo. Justamente ele, a figura que mais se entrega à intensidade do existir, é a que mais se aproxima da vida, sem tocá-la verdadeiramente" (GRAMMONT, 2003, p. 76). O russo vive a intensidade de um sonho, mas esse logo se desvanece para que ele possa se atormentar em face da vida real.

O esteta é aquele que não consegue adaptar sua existência à realidade em seu cotidiano temporal. Por isso cria mundos, paisagens idealizadas em sua consciência. Essa parece ser a sina do homem dos sonhos de Sá-Carneiro, um ser capaz de sonhar a vida e intensamente viver a experiência de um agradável sonho do qual não pensa em acordar. Poetizando sua existência, o que o esteta procura é agregar mais experiências sensíveis a sua vida, preenchendo-se egoisticamente com todas elas. Para Johannes, a sedução é a porta, sendo o método que realiza a dialética do prazer, desfrutando daquilo que idealiza em sua consciência e tentando construir o seu ideal na realidade. Do lado do russo, importa-lhe a permanência no sonho ao invés de encarar a realidade. $\mathrm{O}$ esteta é um indivíduo inconsistente, que vivencia um drama íntimo.

Para Barros (2013), o homem dos sonhos pode ser interpretado como um desdobramento do amigo e narrador-personagem do conto. Em uma leitura freudiana, a partir da obra $\mathbf{A}$ interpretaçáo dos sonhos (FREUD, 1900), a autora atenta para a perspectiva de que o sonho representa a tensão do indivíduo com o mundo exterior, pois revela desejos inconscientes e reprimidos. No desenrolar da narrativa, o sonho toma a forma de uma fuga da realidade, uma vontade desesperada do sujeito por transcender os limites do cotidiano. Assim, o russo seria um desdobramento do eu do narrador, que anseia por uma libertação, por uma vida em contraste com a vida trivial: 
Toda narrativa é uma tentativa de ascensão, de viver o não possível, de sentir sensaçóes não conhecidas, de ir a lugares, de ir a lugares desconhecidos, de possuir a alma e náo somente o corpo; de realizar-se como pessoa e de recusar a vida cotidiana. Esta tentativa, porém, leva à queda, pois a contradiçáo realidade versus sonho destrói o homem misterioso. Para o narrador do conto, a única forma de viver o ideal é desdobrando-se. Assim, o protagonista cria para si um outro personagem, um ser irreal, que voa para o infinito, transcendendo a realidade por meio de sua imaginação, evitando a vida real, o lugar comum (BARROS, 2003, p. 72).

Com base nessa interpretação, o verdadeiro esteta da trama é o narrador-personagem, que alimenta um vazio diante de sua existência por não se contentar com a vida simples, cercada pela rotina, pelos compromissos e obrigaçóes. Necessita esquivar-se desse destino e para isso cria uma extensão de sua existência, um eu imaginário, que possa cultuar suas ideias e aspiraçóes para, assim, experimentar a beleza de seus sonhos. No entanto, o próprio narrador-personagem parece alcançar a consciência da inconsistência de sua ação ao tentar equilibrar a vida vivida com a vida imaginada, pois "toda e qualquer imaginação falha, mostrando que a esfera do real sempre prevalece sobre o universo onírico. $\mathrm{O}$ mundo de sonho não consegue superar o mundo real e é engolido por ele" (BARROS, 2003, p. 71-72).

Kierkegaard acentua que, na estadia estética, o indivíduo permanece no instante e não avança na existência. Seja em estado de consciência ou não, vivencia a tensão entre o interior e o exterior. Amofinado, não consegue amadurecer existencialmente e permanece estagnado, embora nutra a ilusão de que é um homem que experimenta tudo com a maior intensidade possível.

Johannes e o homem dos sonhos estáo tomados pela angústia, disposiçáo singular do indivíduo e assunto tratado por Kierkegaard, em O conceito de angústia, por meio do pseudônimo Vigilius Halfniensis. Kierkegaard ([1844] 2010, p. 45) a define enquanto "a realidade da liberdade como possibilidade antes da possibilidade". A partir dessa definição, a angústia se caracteriza como aquilo que nos direciona a experimentar a sensação da liberdade como fenômeno possível para a vida. Contudo, o indivíduo pode desenvolver com a angústia uma relação negativa. Sendo ela um estado de ansiedade que atormenta e atrai o indivíduo, uma "antipatia simpática e uma simpática antipatia” (KIERKEGAARD, 2010, p. 46), faz com que o indivíduo reconheça-se enquanto um ser-capaz-de, um ser que realiza possibilidades. Para o filósofo, diferente do animal que não pode se angustiar de sua condição e de suas penúrias, pois "em sua naturalidade não 
está determinado como espírito" (KIERKEGAARD, 2010, p. 45), é pela angústia que o ser humano adquire a consciência de ser um sujeito que pode desenvolver a capacidade de se "tornar algo"; pode escolher e, ao escolher, pode escolher-se na existência, ocupando-se dela positivamente.

Johannes e o russo caminham em sentido contrário ao desenvolvimento de uma relação positiva com essa "disposição do espírito", como sublinha Kierkegaard. Tentam em vão alcançar uma realidade que certamente se conflitua com a vida real. Recolhem-se em suas vidas, num estado de abandono de si mesmos. Por isso "o esteta é aquele que vive no possível, no sentido em que tenta desesperadamente realizar todas as possibilidades que se lhe oferecem, mas estas só lhe proporcionam uma atualidade transitória [...]" (GRAMMONT, 2003, p. 53). O esteta se sente como um ser que desfruta de uma liberdade, mas, segundo Kierkegaard, liberdade aprisionada e vazia de conteúdo, pois o esteta não avança com as possibilidades, já que elas não retornam como conteúdo e sentido para sua existência.

Para Kierkegaard (2010, p. 46), até mesmo a criança experimenta a angústia: "observando-se as crianças, encontra-se nelas a angústia de um modo mais determinado, como uma busca do aventuroso, do monstruoso, do enigmático". Para o filósofo, na infância, os indivíduos experimentam a angústia a partir do contato inicial com o mundo, quando se tornam desbravadores, porque a angústia é vertigem de liberdade, uma possível sensação da experiência da liberdade. Johannes e o russo ironizam a vida comum e se consideram autossuficientes em suas ações. O enigmático, o aventuroso e o monstruoso que a criança tomada pela angústia procura são as mesmas experiências ansiadas pelos personagens.

\section{Consideraçóes finais}

Pela perspectiva do estádio estético, possibilidade de existência desenvolvida por Kierkegaard, foi possível identificar semelhanças entre o pseudônimo Johannes e o russo, personagem do conto $O$ homem dos sonhos, de Mário de Sá-Carneiro.

Kierkegaard utiliza um método que atende pelo nome de comunicação indireta, influenciada diretamente pela ironia e maiêutica socráticas. Através de sua metodologia literária, Kierkegaard náo só desenvolve um jogo edificante com os leitores na intenção de despertá-los para a existência, como apresenta as possibilidades de existência que os seres humanos podem atingir em suas experiências singulares e coletivas, traduzidas como estético, ético e religioso. 
Sobre a estadia estética, embora seja tratada vulgarmente como um estádio existencial inferior aos outros dois - o ético e o religioso -, merece adequada importância no projeto filosófico de Kierkegaard. Como salienta Almeida e Valls (2007), o estético representa um lugar estratégico na filosofia do pensador moderno. Representa a concepção de vida da maioria dos indivíduos, medievais, modernos ou contemporâneos: a tensão entre criador e criatura, entre espírito e carne, entre eu e si mesmo.

Pelo viés estético foi possível aproximar o personagem de Sá-Carneiro da filosofia existencial de Kierkegaard. Através de Johannes - pseudônimo arquetípico da possibilidade estética de existência -, constatamos que o dilema enfrentado pelo russo é o mesmo do sedutor: o atrito entre a realidade vivida e a realidade imaginada, a tensão entre a existência poetizada por meio da sedução e do sonho e a existência "real", sujeita a dramas, compromissos e decisóes. O esteta se caracteriza como aquele que se enclausura ao tentar alcançar um prazer que se eternize, atingindo uma medida absoluta. Concentra-se em eternizar aquilo que foge do seu domínio e que logo se esvai: o instante de prazer.

A experiência das personagens estéticas nos direciona à angústia de Kierkegaard. O autor a define como a "possibilidade da liberdade", a liberdade enquanto condição possível para a existência antes de ser alcançada, sendo vislumbrada enquanto rastro, sombra. Nela, o ser humano se percebe enquanto ser-capaz-de, visto que é determinado pela possibilidade. No entanto, Johannes e o russo desenvolvem uma relaçáo negativa com a angústia, pois não avançam nas possibilidades, preferindo a permanência na imediatez. Johannes náo quer se desvencilhar da experiência imediata da sedução, nem o russo quer se desapegar das paisagens e lugares frequentados durante as viagens orínicas. Preferem permanecer na realidade da sedução e do sonho que não estabelecem, por sua vez, laços com a história e com o mundo real, espaço das experiências concretas. Daí, a crise que assola esse estádio existencial: tomando como ponto de partida o efêmero e o temporal, se afastam cada vez mais de uma relaçáo responsável com a existência e com o cuidado consigo próprios. Contemplam uma existência erótica e artística, mediada pelo método da sedução e do sonho e, de fato, não experimentam o "existir" no sentido kierkegaardiano: o tornar-se aquilo que se é, um sujeito autoral de si. 


\section{Referências}

ALMEIDA, Jorge Miranda de; VALLS, Álvaro Luiz de Montenegro. Kierkegaard. Rio de Janeiro: Zahar, 2007.

BARROS, Tania Sturzbecher de. O duplo em Céu e fogo de Mário de Sá-Carneiro. Dissertação (Mestrado em Letras e Estudos Literários). Universidade Estadual de Londrina, Londrina, PR, 2003.

BUENO, Alexei. Introdução: Sá-Carneiro e o Brasil: à procura do último ideal. In: SÁ-

FARAGO, France. Compreender Kierkegaard. Tradução de Ephraim F. Alves. Petrópolis, RJ: Vozes, 2006.

GILLES, Thomas Ransom. História do Existencialismo e da Fenomenologia. São Paulo: EPU, Ed. Universidade de São Paulo, 1975.

GRAMMONT, Guiomar de. Don Juan, Fausto e o Judeu Errante em Kierkegaard. Petropólis, RJ: Catedral das Letras, 2003.

KIERKEGAARD, Sören Aabye. Diário de um sedutor. Os pensadores. Tradução de Carlos Grifo. São Paulo: Abril Cultural, 1979.

. Temor e tremor. Os pensadores. Tradução de Maria José Marinho. São Paulo: Abril Cultural, 1979.

O desespero humano (doença até a morte). Os pensadores. Tradução de Adolfo Casais Monteiro. São Paulo: Abril Cultural, 1979.

Vida e obra. Coleção: Os Pensadores. São Paulo: Abril Cultural, 1979.

O conceito de angústia. Tradução de Álvaro Luiz de Montenegro Valls. 2. ed. Petrópolis: Vozes, [1844] 2010. (Pensamento Humano).

Migalhas filosóficas ou um bocadinho da filosofia de Joáo Clímacus. Tradução de Álvaro Luiz de Montenegro Valls e Ernani Reichmann. Petrópolis, Rio de Janeiro: Vozes, [1844] 2011.

PROTÁSIO, Myriam Moreira. Da genialidade sensível ao amor à norma: existência e consciência em Kierkegaard. Rio de Janeiro: Mauad X, 2014. 
SÁ-CARNEIRO, Mário de. Obra Completa. Introdução e organização de Alexei Bueno. Rio de Janeiro: Nova Aguilar, 1995.

VALLS, Álvaro Luiz de Montenegro. Os sedutores românticos: a força e o método. In: RIBEIRO, Renato Janine (Org.). A seduçáo e suas máscaras: ensaio sobre Don Juan. Sáo Paulo: Companhia das Letras, 1988.

Márcia Manir Miguel Feitosa, Leonardo Silva Sousa Entre a seduçấo e o sonho: uma leitura de "O homem dos sonhos", de Mário de Sá-Carneiro à luz da filosofia de Soren Kierkegaard Submetido em: 2016-03-22 Aprovado em: 2016-05-31 